\title{
TOWARDS ECO-URBAN SETTLEMENT: LEARNING FROM LOW-MID HOUSING VACANCY PHENOMENA IN THE CITY OF BEKASI
}

\author{
A. Adib Abadi \\ School of Architecture, Planning and Policy Development, Institut Teknologi \\ Bandung \\ e-mail: abadi@ar.itb.ac.id
}

\begin{abstract}
Eco-urban settlement is integrated concept of environment sustainability and urban settlement. As a dominant element in urban area, housing plays a critical role in producing sustainable settlement as it significantly influences physical environmental quality as well as social and economic productivity. The provision of decent housing therefore become strategic approach to produce such a strong urban community that will functions as an importance factor in enhancing urban sustainability. However, it is not a simple idea as housing decency is a conditional aspect with regard to heterogeneous needs and housing characteristics. In dealing with urban housing insufficiency, the Government of Indonesia has introduced a housing ownership program for low to mid income people. This strategy in some extent offers social, economic and environmental benefits and forms strong neighbourhood and communities that will be valuable capital for enhancing urban sustainability. However, this strategy does not present its incentives as it puts its orientation on quantitative measure rather than social aspect. This paper exposes the condition of low-mid income housing policy implementation in relation to eco-urban settlement process. The fact that about 40.2\% of abandoned low-mid income houses in the municipality of Bekasi, in West Java, Indonesia indicates the importance of social dimension in dealing with sustainable urban settlement objectives. Regression analysis of data both at macro and micro levels discloses the correlation between low mid people needs and the abandonment. The result shows the importance of integrating social dimension into the housing provision strategy for effectively achieving eco-urban settlement goal.
\end{abstract}

Keywords: eco-urban settlement, low-mid income, housing vacancy, Bekasi

\begin{abstract}
ABSTRAK
Permukiman perkotaan berbasis ekologi merupakan konsep keberlanjutan yang terintegrasi antara lingkungan dan permukiman perkotaan. Sebagai elemen yang
\end{abstract}


dominan di perkotaan, perumahan memainkan peran penting dalam memproduksi permukiman berkelanjutan karena sangat berpengaruh terhadap kualitas lingkungan fisik maupun produktifitas sosial dan ekonomi. Penyediaan perumahan yang layak menjadi pendekatan strategis untuk menghasilkan masyarakat kota yang kuat, yang akan berfungsi sebagai faktor penting dalam meningkatkan keberlanjutan perkotaan. Namun, bukan ide yang mudah seperti keterjangkauan perumahan yang merupakan aspek bersyarat sehubungan dengan kebutuhan dan karakteristik heterogen perumahan. Berkaitan dengan tidak cukupnya perumahan kota, Pemerintah Indonesia telah memperkenalkan program kepemilikan perumahan untuk masyarakat berpenghasilan rendah sampai menengah. Strategi ini pada batas tertentu menawarkan manfaat sosial, ekonomi dan lingkungan dan bentuk lingkungan yang kuat dan masyarakat yang akan menjadi modal berharga untuk meningkatkan keberlanjutan perkotaan. Namun, strategi ini tidak menyajikan insentif sebagai penempatan orientasi aspek kuantitatif daripada aspek sosial. Makalah ini memaparkan kondisi pelaksanaan kebijakan perumahan menengah dalam kaitannya dengan proses penyelesaian lingkungan perkotaan. Fakta bahwa sekitar 40,2\% rumah bagi masyarakat berpenghasilan rendah-menengah di kotamadya Bekasi, Jawa Barat, Indonesia ditinggalkan. Hal ini menunjukkan pentingnya dimensi sosial dalam menangani tujuan permukiman perkotaan yang berkelanjutan. Regresi analisis data baik di tingkat makro dan mikro mengungkapkan hubungan antara rendahnya kebutuhan masyarakat menengah dan ditinggalkan tersebut. Hasil penelitian menunjukkan pentingnya mengintegrasikan dimensi sosial ke dalam strategi penyediaan perumahan agar efektif mencapai eco-urban sebagai tujuan permukiman.

Kata kunci: eco-urban permukiman, pendapatan rendah-menengah, kebutuhan perumahan, Bekasi

\section{INTRODUCTION}

The urban growth in developing countries, including Indonesia, has led to crisis on urban sustainability. The integration of Jakarta with surrounding cities known as Jakarta Bogor Depok Tangerang and Bekasi (Jabodetabek) region, for instance, has created a new mega city. With regard to area development, the municipality of Bekasi has been established as buffer of Jakarta with the role of settlement, trade, and business. As near by the capital, the city has increasingly urbanized. Regional Economic Survey West Java 2005 noted that among those neighbouring cities, Bekasi municipality is the most populated one and has relatively high level of population growth in the last decade. Besides of its positive effects that population growth indeed has discouraged poorer cities in increasing infrastructure per head and in providing an adequate number of houses. 
The fact that housing covers more than $2 / 3$ of urban area (Devas and Rakodi, 1993) indicates the strategic role of settlement on urban sustainability. This sight was supported by Hall and Pfeiffer (2000) that put shelter as one of urban sustainable dimensions because housing conditions is not only concerning physical aspect but also social, economic and cultural dimensions. As such a basic need, house is not only protects people from inconvenience natural condition but also provide a place for socio cultural value development as well as economic generator. Thus decent affordable housing becomes such an essential strategy to enhance urban sustainability which is the objective of eco-urban settlement.

Considering the role of housing on urban sustainability many developing countries try to implement deliberately home ownership program. This scheme is believed to offer positive influences on enhancing urban sustainability at least in such a country of United Stated. With such decent housing supply the program has indicated some improvement on economic productivity, environment quality and social integration (Van Zandt, 2006). The government of Indonesia through its various housing policies has copied the western experiences by establishing the comparable program. Thousands very simple (RSS) and simple houses (RS) have been developed by both public and private developers not only at urban peripheral area but also at sub urban one. In the Bekasi municipality housing demand has arrived at about 100.000 units in 2010. This problem is influenced by very high rate of housing demand of Jakarta which reached to 2.565 units per year in average.

In dealing with housing demand, from 1996 to 2004 the municipality of Bekasi issued 58 housing developments planning encompass 38,315 housing unit and spread out in many locations. Some $60 \%$ of that amount is small type (less than 45 $\mathrm{m} 2$ of size) and is purposed for low-mid income people. In fact, so many of the houses have been left in empty by the owners. This condition is clearly in contrary to the idea of home ownership program which is promoted to increase eco urban settlement process

\section{Methodology}

This paper draws on statistical and other documentary evidence such as Bekasi in Figure, background of the municipality of Bekasi development, list of housing development permit issued by Bekasi Municipality from 1995-2004, as well as government housing policy documents. Theoretical framework is developed from the growing housing research literature on low to mid income housing policy, housing ownership, urban sustainability and eco-settlement. The paper also draws on a case study of vacancy housing in Bekasi Municipality, using empirical field-based research including key informant interviews with municipal officials, chief of district society, and a 350 questioner survey for the housing owners conducted in April 2006 to March 2007 in eight estates sample.

The survey utilized a purposive sampling method to select respondent that represented the opinion of low-mid housing owners in the city toward the condition of 
their housings. Survey questions were based on the advice of key informants, and insights from the literature, and targeted issues and interrelationships among issues of housing and eco urban settlement idea. And co-relation analysis is carried out to find relationship between housing needs on housing and settlement characteristic which is indicated by leaving their houses in vacant. The conclusion then was drawn by comparing the reasons with the concept of eco urban settlement.

\section{Theoretical Framework}

Eco urban settlement is an approach to development, which basically set about achieving housing delivery through a step-change in quality of place and quality residential offer in existing urban areas. This offers opportunities to develop sustainnable communities that important resource for enhancing urban sustainability. The idea itself is developed from eco city concepts which constitute a special segment of the sustainable settlement aspirations.

The eco-city is an umbrella metaphor that covers a wide range of urban-ecological schemes that aim to achieve urban sustainability. White (2002) explains the eco-city as 'a city that provides an acceptable standard of living for its human occupants without depleting the ecosystems on which it depends'. Similar to the concept of sustainability, eco-cities are set in a subject of tensions between maintaining or creating an acceptable standard of living for all people on one hand, and the capacity of the environment to fulfill the needs of present and future generations. Eco city as an environmentally, socially and economically responsible city indeed resonates with the concept of sustainability (Kunz, 2006).

Of several views it is clear that the ultimate objective of both eco-city and sustainnable city is to improve the urban condition and create livable cities. But both ideas are very abstract thought and therefore they need to be down to more realistic development circumstance. To simplify such very complicated urban condition, Hall and Pfeiffer (2000) suggest several essential elements that play influential role on urban sustainability in which housing is one of those besides of economy, society, environment, access, life and democracy.

In deeply insight of sustainable concept also indicated two critical points: process and human needs. Eastaway and Stǿa (2004) mention that housing and urban sustainability have to be understood as a process rather than a product so that the concept deal with time dimension of changes for future generations. This concept looks compatible to the condition of urban poorer that used to meet their housing needs gradually. In association to urban housing development the process can be seen in the stages of dwelling process which shows a pattern of interaction among people, settlement and the nature. Chase-Dunn (2005) added that not only have dwelling process evolved along with the rise of social complexity and hierarchy, but they have also played a generative role in human social development at several crucial moments. 
In addition the notion of process shows the complexity of inherently multi aspects involvement as it is in parallel to housing characteristics. Hall and Pfeiffer (2000) mention that low to mid housing policy will not be enough only by financial assistance but it has to focus more on enabling strategy. By this strategy housing supply provide more than shelter that offer environment that can function as a place for process of meeting the entire housing needs.

Indeed meeting human needs is another critical aspect of sustainability. Housing needs actually can be identified from housing ownership motives. By referring to Maslow's need hierarchy, Harris et.als (1983) reveals relationship between ownership motives and housing dimensions. The motives are determined by the dynamic of socio-economic characteristics, family expectation mobility and housing market condition (Rohe et.als, 1996). For low-mid income people the level of housing motives is mostly influenced by its housing affordability which tends to take their priority into the first two lowest levels: physiological and safety (Tabel 1). However Morrow (2001) reminds that affordable housing policy also has to consider housing decency which is very important for improving opportunity of economic, social and environment sustainability (Byrne, 2007; Hall and Pfeiffer, 2000).

Table 1. Dimensions of Housing Characteristics and Housing Motivation

\begin{tabular}{|c|c|c|c|}
\hline \multirow{2}{*}{$\begin{array}{l}\text { Motivation } \\
\text { Level }\end{array}$} & \multicolumn{3}{|c|}{ Dimensions of Housing Characteristics } \\
\hline & Physical & Social & Economic \\
\hline Physiological & $\begin{array}{l}\text { Sound structure } \\
\text { offering basic facilities }\end{array}$ & $\begin{array}{l}\text { Location convenient to } \\
\text { employment and transportation }\end{array}$ & Low possible cost \\
\hline Safety & $\begin{array}{l}\text { Adequate privacy for } \\
\text { family unit }\end{array}$ & $\begin{array}{l}\text { Freedom from environmental } \\
\text { hazards and uncertainties of } \\
\text { rental market }\end{array}$ & $\begin{array}{l}\text { Ability to exercise control } \\
\text { over home environment }\end{array}$ \\
\hline Belonging & $\begin{array}{l}\text { Adequate privacy for } \\
\text { each individual }\end{array}$ & Socially compatible neighbours & $\begin{array}{l}\text { Acceptance into community } \\
\text { of other homeowners }\end{array}$ \\
\hline Esteem & $\begin{array}{l}\text { Attractive home design } \\
\text { and landscaping }\end{array}$ & Prestige address & $\begin{array}{l}\text { Pride in owning an asset } \\
\text { with appreciation potential }\end{array}$ \\
\hline $\begin{array}{l}\text { Self- } \\
\text { actualization }\end{array}$ & $\begin{array}{l}\text { Facilities for a } \\
\text { vocational pursuit }\end{array}$ & $\begin{array}{l}\text { Proximity to aesthetical, cultural, } \\
\text { and recreational interests }\end{array}$ & $\begin{array}{l}\text { Expression of commitment } \\
\text { to specific set of value }\end{array}$ \\
\hline
\end{tabular}

Source: Harris et al, 1983

Indeed, housing decency is multi dimensions that encompass technical and non technical aspects such as security of tenure, expensive spend, and habitability as well as economic supportive location (Hall and Pfeiffer, 2000). Under that criteria housing supply has to bring decent environment by providing basic infrastructure such as water and sewerage, technically sound, access to public transport (Belsky et.al., 2001). The decency can be assessed from the level of its occupancy (van Zandt et.al, 2006). In some extend the occupancy level reflects owners' rational respond toward housing condition (Grimes et.als, 2006) and gap between housing capacities and housing needs. Moreover Bassett et.als., (2006) classifies the vacancy into 2 categories. Vacant houses are the houses that have been left in vacant for less than 6 
months in a year. While abandoned ones have not been inhabited for more than 6 months and are in bad condition, indecent, and need special treatment.

Regulations and housing policy thus become significant instruments to produce decent and affordable housing. They are needed to ensure access and affordability of low to mid income people (Dowall, 1992; Erguden, 2001; Priemus, 2006) to minimize housing indecency (Freeman, 2002) as well as to ensure housing ownership (van Schie, 2006). The ownership theoretically offers opportunity and safety upon low-mid income group better future life (Turner, 1976 and Bassett et.als., 1980). Basolo and Strong (2002), Mulder (2005) and Cho et.al. (2006) argues that housing ownership offers broad control to the house and opportunity to occupy their houses continuously (Harrris et.al, 1983). Therefore this ownership can make stable neighbourhood. Beside creating control system towards social behaviour of residents (Van Zandt, 2006), the neighbourhood will develop environment main-tenance mechanism which are essential requirement for sustainable housing (Roseland, 1998; Winston, 2009). This process is actually the main idea of eco urban settlement to improve their quality of life.

\section{RESULTS AND DISCUSSION}

\section{Solutions for Housing Need: Understanding Low to Mid Income Housing Need}

Housing need of low to mid income people is characterized by some social background. The housing ownership motives of low mid income families are mainly safety reason $(54.6 \%)$. At the time they do not have owned houses yet and rent $(55.6 \%)$ relatively spacious houses for accommodating at least 4 family members $(58.5 \%)$. Most of them try to be close to workplace by living in Jakarta $(60.2 \%)$ where most of government offices are situated. That temporary housing needs reflect their productive stage as the most families are in between 41-50 years old (69.4\%) and still have 5-15 year of time to work. Although they earns not enough money but their career as civil servant $(75 \%)$ that offer regular salary gives opportunity to get housing mortgage for buying their own houses. In addition the families seem to put their financial priority to provide higher education for their children than the parents who mostly only holds high school qualification (58.3\%).

\section{Low-mid Income Housing Condition}

The Bekasi municipality is a medium sized city. Today it is fragmented by suburbs and townships, struggling with diverse of social, economic and environmental conditions and strongly marked with enduring social and environmental, infrastructure and service inequalities. Low-mid income housing locations are scattered, mainly in Southern part which is relative new area development (Figure 1). So far all area has been supported by public transport but the condition and the level of services are varied. In stable settlement such as South Bekasi, Pondok Gede, West 
Bekasi, East Bekasi, and Northern part of Rawa Lumbu, access to public transport both city transport and taxi are very easy. But for housings out side of those 5 districts, access to public transport is relatively hard.

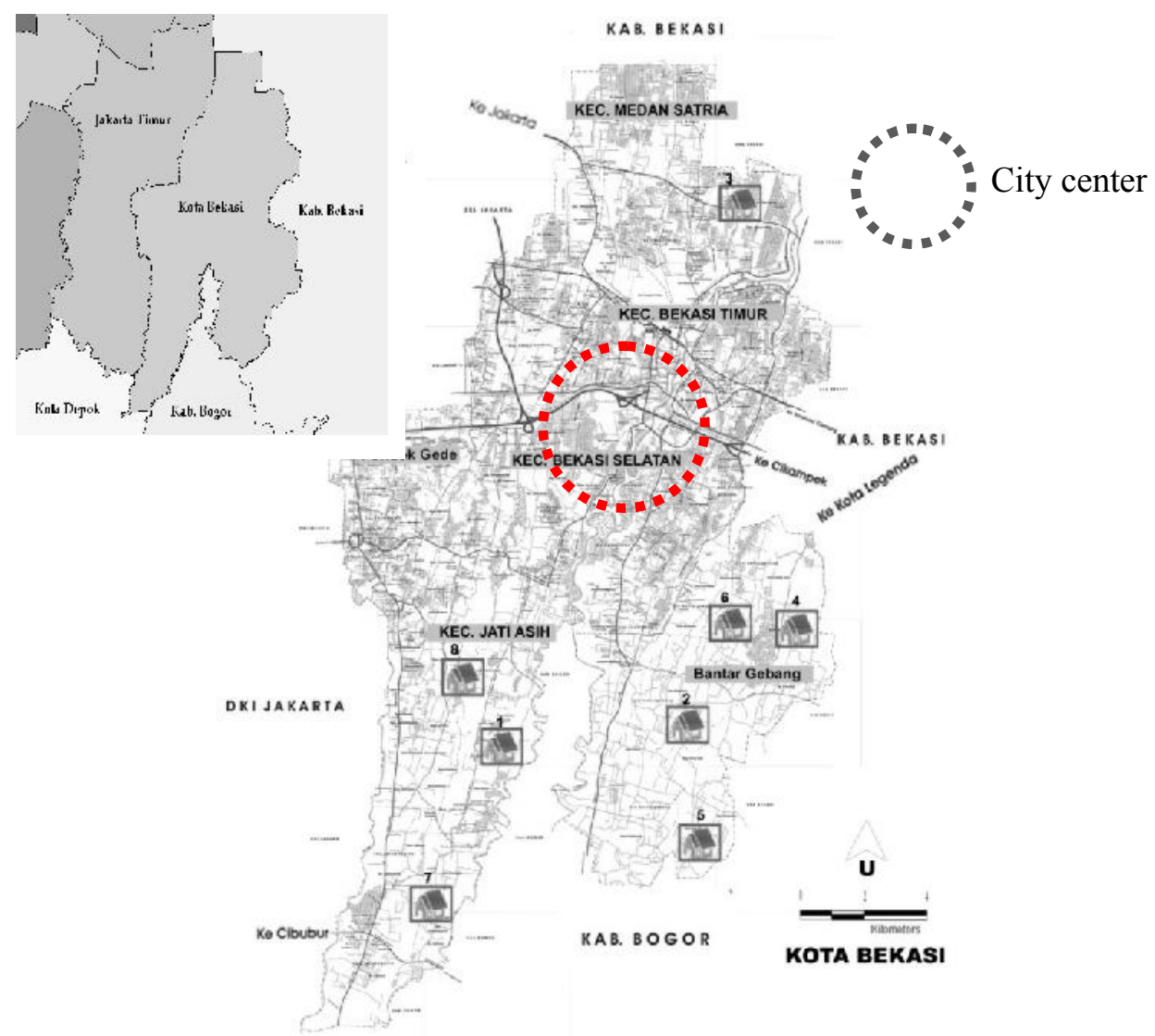

Figure 1. Location Distribution of High Level of Housing Vacancy in Bekasi Source: www.kotabekasi.go.id, 2005

The level difficulty of access to public transport seems to be parallel with the distance to city centre. The more distance of housing from the city center, the more difficult access to public transport. For the reason, people who live in housings at Bantar Gembang district used to have private transport either motorcycle or car for going to school and work place which is mainly in Jakarta.

\section{Housing Vacancy Condition}

In general the housings locate mainly in the Southern area except Bumi Alinda Kencana, situates in Northern part of the city which is in fact is relatively more mature development area and close enough from city central. The detail distribituon and total number of vacant low-mid income houses is displayed in Table 2. 
Table 2 . Housing Estate in the City of Bekasi with High Level Vacancies

\begin{tabular}{lllll}
\hline \multirow{2}{*}{ Housing Estate } & \multirow{2}{*}{ Sub-district, District } & \multirow{2}{*}{ Type(m2) } & \multicolumn{2}{l}{ Vacant Houses } \\
& & & & \\
& & 36 & 68 & $(23.45)$ \\
Puri Gading II & Jatiluhur, Jatiasih & 63 & $(29.72)$ \\
Bumi Alam Hijau & Pedurenan, MustikaJaya & 36 & 63 & $(9.57)$ \\
Bumi Alinda & Kaliabang Tengah, Bekasi & 36 & 58 & \\
Kencana & Utara & & & $(22.47)$ \\
BKKBN Pusat & Mustika Jaya, Mustika Jaya & 21 & 83 & $(68.85)$ \\
Perum Dep PU & Sumur Batu, Bantar Gebang & 21 & 935 & $(20.94)$ \\
Griya Mustika Sari & Mustika Sari, MustikaJaya & 36 & 67 & $(54.87)$ \\
Inti Alasindo Permai & Jatisari, Jatiasih & $21 / 36$ & 62 & $(35.84)$ \\
Peg PT Asabri & Jatiasih, Jatiasih & 36 & 162 & \\
\hline
\end{tabular}

Source : Abadi (2009)

There are some influential reasons concerning housing owner decision to let their houses in vacant. This reason relates to infrastructure condition and public facilities. Housing infrastructures such as water, electricity and residential street are considered as inadequate. There is no water provision so people that intent to reside in their small houses do have to provide water by themselves by making well. Although those estates were planned but residential street is very poor and sanitation is unwell designed.

People also have to spend extra money for improving residential street and drainage to make up the environment. Housing is also considered related to undersupply public transportation. People who live in Kompleks Perumahan Departemen Pekerjaan Umum and Bumi Alam Hijau for instance need extra cost for trans-portation because the housings have not been served by public transport regularly. This is reasonable reason since for most of the owner who works in Jakarta as they need at least one and half hour to reach their working place. Beside that, housing space is considered as insufficient. The vacant houses owners also assumed that $21 \mathrm{~m} 2$ of house is insufficient for families consist of 4 members.

Housing vacancy at low-mid income housing in the city of Bekasi can be categorised into abandoned ones as most of them (98\%) has been left in vacant for more than 6 months. In this case, $6 \%$ of the sample had ever used for less than 1 year but about $81 \%$ of the vacant house category has never been used at all. The latter fact also indicates such a speculation that is making profit from buying the houses. However it seems not compatible with financial condition of low mid income people as housing business is not high liquidity one. This condition tends to become saving strategy for securing its future houses needs.

\section{The Problem of Decent Affordable Housing}

The vacancy explains rational responses' housing owners concerning poor housing condition at particular location. Housing has inadequate capacity (35\%) to fulfil 
social and spatial needs. The results of regression analysis of the housing vacancy factors describes that the vacancy is combination of housing characteristic and housing needs ( Table 3 ).

Table 3. Regression of reason to leave low mid income houses in vacant

\begin{tabular}{lll}
\hline Parameter Estimates & $\begin{array}{l}\text { Responses } \\
\text { Housing decency / distance to workplace } \\
\text { Estimates }\end{array}$ & $\begin{array}{l}\text { Spatial sufficiency } \\
\text { Estimates }\end{array}$ \\
\hline Building size & $-0.331+$ & 0.000 \\
Pension residence & 0.000 & $0.302+$ \\
Access to public transport & $-0.232^{*}$ & 0.089 \\
Environment quality & $-0.598+$ & -0.068 \\
Lot size & 0.000 & $-0.327+$ \\
\hline
\end{tabular}

Sources : data survey, 2006

Note: significance level $\mathrm{F}<0.05,+$ liberal $\mathrm{F}$, significance level $\mathrm{F}<.0001$

Chi-square=4.780 (5 df); Probability level (p)=.443; GFI=.988; AGFI=.931; RMSEA=.000.

Correlation indicates that the reasons of housing decency will be getting stronger in along with the decrease of satisfaction level on public transport access and environment quality, as well as the with the decline of buying priority on housing size. Factor correlation also points out that the housing decency factor is influenced by difficult access to public transport and by very small housing size. Meanwhile factor of spatial sufficiency is determined by lot size and motivation for securing their residence in retirement age. This reason is strongly influenced by the fact hat most of low mid income people does not have their owned houses. The option to leave the houses in vacant seems to happen because of physical characteristic of low mid income housing ( $R S S$-simple houses) could not meet at present housing consumption level of low mid income families.

Those factors related both housing decency are required to support all domestic activities and will cause great problem for occupying their houses. The housing condition is considered very expensive for the people as it needs some extra budget to reside their own houses. The cost also arises due to difficult access and limited public transport (33\%). All above condition is worsened by size of the house that needs some expansion in order to have acceptable house space that can accommodate the whole family members decently. It seems that impossible to make bigger their houses this time as they put their financial plan priority on education.

The need of large amount budget causes some constraints for low-mid income people to reside their own houses and therefore they let the houses in vacant in prolonged time. Consequently, there will be no strong community creation. Therefore it is very common for housing with high level of vacancy to have poor environment condition as there is no urban housing environment improvement. Therefore the existence of vacancy can indicate the low use value where situation indirectly indicates will decrease housing capacity to enhance sustainable urban housing. 


\section{CONCLUSIONS}

Low-mid income housing development is reasonable effort to support the idea of eco urban settlement if it considers the quality of housing as integral part of affordable housing policy. However the stress on affordability has caused developers to produce indecent houses which were incapacity to develop stable settlement. It is mainly because there was mismatch between characteristics of affordable housing and the dynamic owner's housing needs. As the result, housing ownership program that suppose to provide positive impact for urban sustainability goes contrarily and to waste both economic and environment resources.

This paper aimed at understanding the problem of enhancing eco-urban settlement. An analytic framework was conceptualized and juxtaposed within a critical analysis of the housing needs approaches for addressing sustainability. The idea was integrating sets of human dimensions in the affordable housing program by which could create strong urban community. However the outcomes of implementing home ownership program would be bad example that requires re-consider throughout the program's approach. It is believed that this program with a continued effort current sustainable practices must be done at the dynamic human dimensions of housing needs so it can shape stable community that led to future better urban settlement. The disregard of social dimension as it is in low to mid income housing provision strategy indeed will take the urban environment far away from eco-urban settlement goals.

\section{ACKNOWLEDGEMENTS}

This paper is small part of research on housing vacancy held in 2005 which is undisclosed in my dissertation. Thanks to my supervisors who encourage me to write more papers from the available collected data.

\section{REFERENCES}

Abadi, A. A. (2009), Phenomena of Housing Vacancies at Mid Low Income Housing in the Municipality of Bekasi, Dissertation, Study Program of Architecture ITB, Bandung.

Basolo, V. Strong, D. (2002), Understanding the Neighborhood: From Residents' Perception and Needs to Action, Housing Policy Debate, 13 (1), 83103,Fannie Mae Foundation pp. 83-103.

Bassett,E.M., Schweitzer J.Panken, S. (2006), Understanding Housing Abandonment and Owner Decision-Making in Flint, Michigan: An Exploratory Analysis, Lincoln Institute of Land Policy, Working Paper. 
Belsky, E.S. Lambert,M.(2001), Where Will They Live: Metropolitan Dimensions of Affordable Housing Problems, Joint Center for Housing Studies, Harvard University, Discussion Paper, September.

Byrne, J.P. Diamond, M. (2007), Affordable Housing, Land Tenure and Urban Policy, Fordham Urban Law Journal, 34.

Cho, Y. and Whitehead, C. (2006), Affordable Low Cost Home Ownership: A Case Study, ENHR International Conference, 2-5 July, Ljubljana, Slovakia.

Devas N. Rakodi, C. (1993), Managing Fast Growing Cities: New Approaches to Urban Planning in the developing World, Addison-Wissley Longman Scientific Ltd., London.

Dowall, D.E. (1992), Benefits of Minimal land-use Regulation in Developing Countries, Cato Journal, Fall, 12 (2).

Eastaway, M.P. Stǿa, E. (2004), Dimensions of housing and urban sustainability, Journal of Housing and the Built Environment, 19, 1-5.

Erguden, S. (2001), Low-cost Housing. Policies and Constraints in Developing Countries, International Conference on Spatial Information for Sustainable Development, 2-5 October, Nairobi, Kenya.

Freeman, L. (1998), Interpreting the Dynamic of Public Housing: Cultural and rational Choice Explanations, Housing Policy Debate, 9 (2), 323-352,Fannie Mae Foundation.

Grimes, A. Kerr, S. Aitken, A. Sourell, R.(2006), The Housing Fulcrum: Balancing Economic And Social Factors In Housing Research And Policy, Kõtuitui : New Zealand Journal of Social Sciences Online, 1, 65-79. Royal Society of New Zealand

Hall, P. Pfeiffer, U. (2000), Urban Future 21. A global Agenda for Twenty first Century Cities, E\&FN Spon and Federal Ministry of Transport, Building and Housing, New York.

Harris, I. Young, S., (1983) Buyer Motivation = Human Needs, Real Estate Today, June.

Kunz, J.(2006), Social Sustainability and Community Involvement in Urban Planning: Lessons from the Eco-City Project, Housing and Environment ,8.

Morrow, M.J.(2001), Affordable Housing Policy: Integration of Land Use Tools and the Role of the State Growth Management, Major Paper for Master of Urban and Regional Planning, Virgina Polytechnic Institute and State University.

Mulder, C.H. (2005), Home-ownership and family formation, Paper for Annual Meeting of the Population Association of America.

Priemus, H. (2006), European Policy and National Housing System, ENHR Conference, 2-5 July, Ljubljana, Slovenia.

Rohe, W.M. Stewart, L.S. (1996), Homeownership and Neighborhood Stability, Housing Policy, 7 (1), 37-81, Fannie Mae Foundation.

Roseland, M.(1998), Toward Sustainable Communities, New Society Publishers Gabriola Island BC, Canada.

Turner, J.F.C.(1976), Housing by People, Toward Autonomy in Building Environments, Marion Boyars, London.

van Schie, Els CM. (2006), Knowledge-based housing policy: The Dutch Example, ENHR International Conference, 2-5 July, Ljubljana, Slovakia. 
Van Zandt, S. (2006), The Costs and Benefits of Home-ownership, Center for Urban and Regional Studies. University of North Carolina at Chapel Hill.

White, R.R. (2002) Building the Ecological City, Cambridge, Woodhead Publishing Ltd.

Winston, N. (2009), Urban Regeneration for Sustainable Development: The Role of Sustainable Housing?, European Planning Studies, 17 (12), 1781-1796. 